\title{
HRM Practices in Hotel Industry
}

\section{Wayan Gede Suharta Dewantara ${ }^{1}$, Siti Haerani² and Nurdjanah Hamid $^{3}$}

\author{
${ }^{1}$ Vale Indonesia, Indonesia, e-mail: Wayan.dewantara@gmail.com \\ ${ }^{2}$ Hasanuddin University, Indonesia \\ ${ }^{3}$ Hasanuddin University, Indonesia
}

\begin{abstract}
This research has the aim to uncover human resource practices in the hospitality industry. This research hopes to support and build insights and theories about the practice of Human Resources. This qualitative research begins with a literature study on HR practices, which will be confirmed through a series of interviews with Human Resources practitioners to get key information, deepening, and important findings. The research found several HR practices which are implemented equally between managers and staffs such as the job designs, training and development. The research also found that specific distinctions applies to Manager role in accordance to the Decision Making and Goal setting. Other relevance HR activities were revealed from the study that can be referred by HR practitioners such as family and staff gathering, implementation of KPI and Balanced Scorecard, also the utilization of Employee Engagement Index and Survey. The research was conducted in the hospitality services industry in South Sulawesi \& Bali which can be used as a reference for research into HR practices or research in the next hospitality field. This research can be used as a reference for policy makers or HR practitioners to understand standard practices or choose best practices that can be applied to the development of this field in the future. This study provides new value in the identification of HR practices that are applied to employees and leaders / managers.

Keywords: High Commitment Work Systems, Human Resources, Hotel
\end{abstract}

\section{Introduction}

In its Regional Economic and Financial Study in August 2018, Bank Indonesia explained the future challenges for the Indonesian economy regarding external and domestic conditions which tend to be increasingly dynamic, thus requiring efforts to strengthen the structure of the national economy to maintain sustainable economic growth. The tourism sector has the potential to be a driver of future economic growth. Tourism sector development is expected to accelerate foreign exchange receipts which in turn can improve the current account deficit. Various investments and provision of infrastructure supporting tourism will be able to create jobs and promote sustainable and more inclusive economic growth (Bank Indonesia Aug 2018).

Tourism is the largest employer industry (UN WTO cited in Davidson, McPhail \& Barry, 2011), so human resource management will be an integral part of the organization following a SHRM model (Davidson, McPhail \& Barry, 2011). Management of a company is generally carried out by company leaders / managers.

While the tourism industry objective is principally to increase profits, the objective for a destination country in term of economic point of view is to increase its share of income, employment and so forth (Nuryanti, 2001). Playing in a demand-supply relationship within economic point of view, tourism has three important aspects as a flow of income, trade and foreign exchange (Nuryanti, 2001).

The importance of managing large numbers of workers in the tourism industry in countries is recognized by the World Travel and Tourism Council (Nickson, 2007). Although the number of workers is very significant, the quality of the work is still doubtful.

Companies and managers in the tourism industry face challenges when deciding to carry out the recruitment, development and management process of a committed, competent, well-managed and motivated workforce that can provide quality end results (Nickson, 2007). 
For this reason, proper understanding is needed to uncover hidden factors in HRM practices and policies so that they can build optimism in the management of human resources (Nickson, 2007).

With a focus on the field of hospitality, this research seeks to obtain information on what Human Resources practices are carried out in this field to employees and to the leaders / managers of the company. Our research is then continued to identify HR practices that apply equally and differently to leaders / managers and company employees.

High Commitment Work Systems. Using the finding from their research in telecommunication industry, the high commitment work system provides an impact on innovative work behavior (Ahmed et al, 2018).

The high commitment work systems (HCWS) conducted by HR is trying to focus on practices that are determined to set an effect on increasing the levels of commitment felt by employees toward their job and the efforts they put into their work (Ahmed et al, 2018). Human resource management that is managed effectively can drive good economic performance. Referring to various studies, literature, and direct observation and experience, Pfeffer (1998) focuses on 7 (seven) basic dimensions in the management of human resources namely:

a. Employment security,

b. Selective hiring of new personnel,

c. Self-managed teams and decentralization of decision making as the basic principles of organization design,

d. Comparatively high compensation contingent on organizational performance,

e. Extensive training,

f. Minimize any distinction and barriers status, including dress, language, office arrangements and wage differences across levels, and

g. Extensive sharing of financial and performance information throughout the organization. Unitarist and Pluralist views in HR Management. Human Resource Management can be grouped into two approaches, namely (Davidson, McPhail \& Barry, 2011):

a. Unitarian, an approach based on the assumption that there are similar interests between employers and workers, thus encouraging commitment from both parties and

b. Pluralism, an approach that recognizes a conflict of interest between employers and workers so that HRM must be negotiated and resolved to achieve company goals

The two approaches above provide the basis for HR researches and the development of management and industrial relations theory.

Applying management practices separately will not produce results and on other occasions can be counter-productive (Pfeffer, 1998). Because this requires time both for implementation and to see results in real terms, a long horizon view is required to develop and build a high-performing organization (Pfeffer, 1998).

Based on a survey of nearly 1,000 companies to study thoroughly of the relationship between the practice of Human Resources and Company Performance, this HR practice has a significant economic and quantitative impact on employee outcomes (turnover and productivity) and on the scale of the company's short and long-term financial performance (Huselid, 1995).

HR practices are source of company competitiveness (Lado \& Wilson, 1994). These practices refer to set of practices that are carried out consistently to improve employee knowledge, skills, abilities and motivation (Ngo, Lau \& Foley, 2008).

Ngo, Lau and Foley (2008) used three variables in the form of financial performance, operational performance and employee relations climate, HR practices that were asked to the HR Director, including the selection process, performance appraisal, compensation package, employee training and development, employee turnover, contribution employees, long-term rewards (Ngo, Lau \& Foley, 2008). 
Empirical research by Oladapo and Onyeaso (2013) on 240 motels in the United States found that the human resource practices associated with merit-based HR Management and HRM Evaluation were able to predict innovation within the organization.

HRM in Tourism. The four principals necessary to tourism take-off are market awareness/ position, availability of investment capital, accessibility and human resources (Parnwell, 2001). Organizations benefit from employee involvement such as behavior and productivity, even with different results. A survey to 155 companies, that tried to ask about different employee involvement practices and the emergence of support or obstacles from middle managers, found that employee involvement was decreased when the barriers of the manager appeared. The study supported that managers inhibit the existence of employee involvement practices related to personal interest (self-interest), namely loss of manager's work and reduction of layer / delayering. However, some things that led to the emergence of managerial obstacles include lack of close systems and organizational structure of employee involvement goals and unclear and fragmented senior manager support to support employee involvement (Fenton-O'Creevy, 1998).

Preserving the organization culture is relied on the Human Resources section and their selection skills (Ryan, Page \& Aicken, 2005). In organizations that prioritize service and guest satisfaction, the Human Resources department role is important to ensure that recruited and trained employees have the spirit of serving (Kemp, Sharon in Ryan, Page \& Aicken, 2005).

Manager acts significantly in utilizing organization culture. In the comparison to managers who use a participatory approach, organizational culture acts as extension of organizational strategy. Managers interact more frequently with their subordinates as their team members. The return of this interaction is that a new initiative can be implemented quicker and less time and effort spent on fighting the negative feelings held by staff (Ryan, Page \& Aicken, 2005). The culture-based strategy can achieve a firm commitment from management and staff to the organization's goals and strategies by encouraging the development of opportunities (Ryan, Page \& Aicken, 2005 page 249).

\section{Research Methodology}

Bali is Indonesia's most important tourist destination (Nuryanti, 2001). However, the growth of hotels and accommodation rooms in Sulawesi on average is $345 \%$ higher compared to Bali as a tourism benchmark in Indonesia which is $147 \%$. South Sulawesi is the province in Sulawesi which has the largest number of hotels and rooms in 2016 (processed from Badan Pusat Statistik n.d.)

\begin{tabular}{|l|r|r|r|r|r|r|}
\hline \multicolumn{1}{|c|}{ Province } & \multicolumn{1}{c|}{2011} & \multicolumn{1}{c|}{2012} & \multicolumn{1}{c|}{2013} & \multicolumn{1}{c|}{2014} & \multicolumn{1}{c|}{2015} & \multicolumn{1}{c|}{2016} \\
\hline BALI & 22794 & 24215 & 24860 & 28811 & 31596 & 33599 \\
\hline SULAWESI UTARA & 1907 & 2180 & 2182 & 2165 & 2757 & 2576 \\
\hline SULAWESI TENGAH & 227 & 201 & 394 & 523 & 742 & 766 \\
\hline SULAWESI SELATAN & 3657 & 3683 & 3620 & 5415 & 5392 & 6475 \\
\hline SULAWESI TENGGARA & 495 & 564 & 699 & 1036 & 1326 & 1295 \\
\hline GORONTALO & 54 & 54 & 258 & 354 & 470 & 471 \\
\hline SULAWESI BARAT & 131 & 369 & 393 & 387 & 364 & 374 \\
\hline
\end{tabular}

Table 1. Number of Hotel \& Accommodation rooms in Bali and Sulawesi (2011 - 2016) 


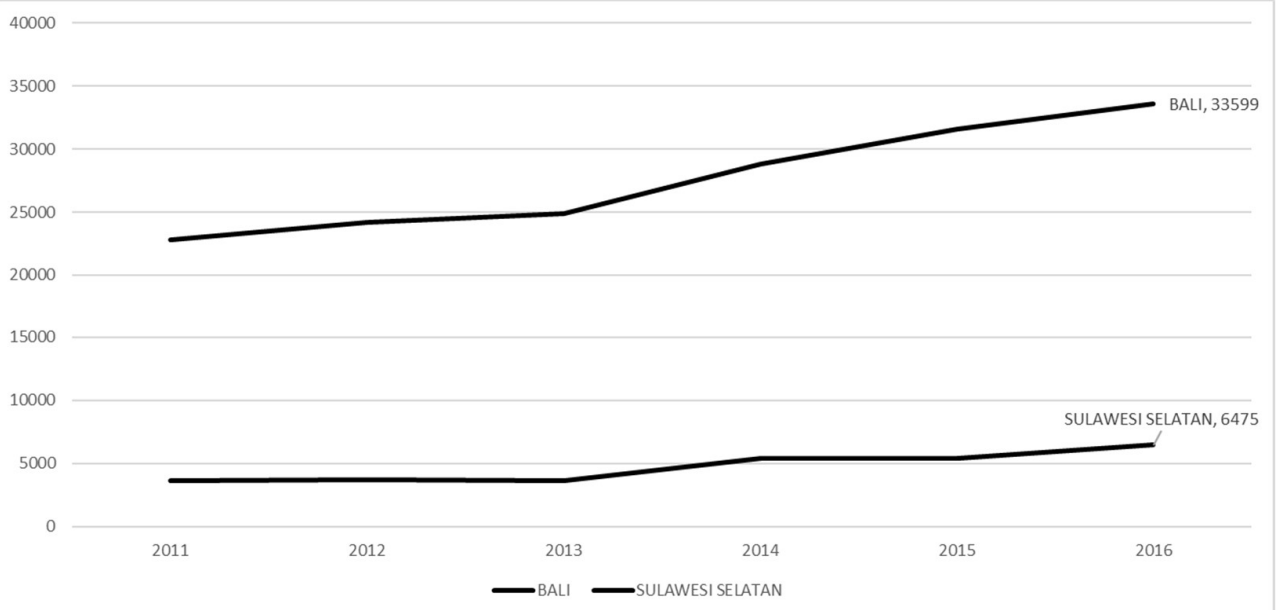

Picture 1. Growth of Hotel \& Accommodation Room in Bali dan South Sulawesi (2011 - 2016)

The qualitative research was conducted by submitting questionnaires to two groups of Human Resources practitioners from Bali and South Sulawesi, focused on practitioners engaged in the tourism and hospitality industry. The response was given by 10 participants and 8 participants came from the hospitality industry.

Respondents of the survey came from the hospitality industry in Bali ( 2 companies) and South Sulawesi (6 companies) consisting of 1 hotel manager, 6 human resource managers and 1 human resources staff. The involved companies consist of two 3-star hotels, three 4-star hotels, one 5-star hotel and one company engaged in accommodation / property.

The work period of the respondent consists of 4 people with a work period of 1 - 3 years in the current position, 2 people with a work period of less than 5 years and 2 people with a service period of more than 5 years.

Respondents who submitted their responses online were then queried with more in-depth interviews individually. The online questionnaire is structured referring to the measures developed by Kwon, Bae \& Lawler (2010) with the following questions:

1. Job Design (3 questions):

a. Companies provide same autonomy between managers and staff employees;

b. The company provides equal opportunities for managers and staff employees to determine and manage their work rules and objectives;

c. The company provides challenging work both to managers and staff employees;

2. $\quad$ Role in Decision Making (2 questions):

a. Both managers and staff employees are given the same opportunity to provide advice and input on business activities;

b. The company provides equal opportunities to managers and staff employees to be involved in decision making;

3. Employee Training and Development (1 questions):

Training and development are given equally to managers and other employees to improve employee skills and knowledge;

4. $\quad$ Performance based payments (1 questions):

The company pays according to the performance of both the managers and staff employees;

5. Payment Rate (1 questions):

On average, companies provide payments to managers and staff employees high enough for similar jobs in other companies;

6. Performance assessment (2 questions): 
a. The company organizes the same performance appraisal process between managers and staff employees;

b. How the company conduct an accurate performance assessment process.

Each question is followed with a free text so that the participants will be able to enter a further explanation if available.

\section{Result and Discussion}

All results from the online questionnaires and in-depth interview were classified in the following analysis.

Job Design.

1. Responses from $75 \%$ of the participants show that both managers and staff employees are provided with work autonomy.

2. The responses show that both managers and staff employees are provided with opportunities to determine and manage their work rules and objectives.

3. All responses show that managers and staff employees should expect the job design for them are equally challenging.

4. Other information provided by the participants are:

a. job description is provided to all employees and managers;

b. the job description incorporates targets or KPIs in income, costing and development for the employees;

c. job description is designed for each level.

Role in Decision Making.

1. Majority of the responses or $87.5 \%$ of the responses show that both managers and staff employees are given the same opportunity to provide advice and input on business activities.

2. Only $62.5 \%$ of the responses show that the opportunity is equal for managers and staff employees to be involved in decision making.

3. Other information provided by the participants are:

a. utilizing balance scorecard in decision making;

b. brainstorming as part of the decision-making process;

c. decision is developed referring to the company core vision, mission and values;

d. the involvement is required since the result is important for the company and the employees;

e. the role in decision making is distinguished since the decision makers are at supervisor role or above.

Employee Training and Development.

1. All participants respond that managers and staff employees are given training and development equally.

2. Other information provided by the participants are:

a. utilizing Training Needs Analysis (TNA), which can be defined at department level or Return of Training Investment (ROTI) as part of the development process;

b. having a specific target of training \& development hours for each employee;

c. in-house training is provided regularly;

d. provisions of several training types are available such as leadership/ managerial, language, skill development, motivational training and including outbound and team-based training;

e. training is programmed and scheduled for every employee.

Performance based payments.

1. A quarter of the responses show that their company did not pay according to the performance of Managers or Employees.

2. Other information provided by the participants are:

a. companies are utilizing salary scale for positions;

b. referring to the regulated minimum wage as the baseline; 
c. implementing performance allowance.

Payment Rate.

1. One response or $12.5 \%$ of responses shows that the payments to their managers and staff employees are not high enough for similar jobs.

2. Other information provided by the participants are:

a. implementing a market positioning pay line e.g. p50;

b. referring to the salary structure and scale for the positions;

c. payment is implemented based on agreement.

Performance assessment

1. Third quarter of the responses conduct the same performance appraisal process between managers and staff employees.

2. Most of the participants $(75 \%)$ indicate that the criteria and procedure of the performance appraisal are clear for the employees.

3. To strive for an accurate performance assessment process, companies may choose the following options:

a. providing the feedback and appraisals regularly (annual, monthly, bi-weekly);

b. conducting one-on-one session between superior and employees;

c. linking the appraisal with employee development;

d. conducting $180^{\circ} / 360^{\circ}$ feedback of performance appraisals;

e. conducting the feedback session within 6 months duration;

f. implementing balanced scorecard;

g. referring to employees' KPI;

h. performing an evidence-based appraisal.

In this research, several questions asked related to high commitment work systems which consist of work design, participation in decision making, employee training and development, performancebased payments, payment/ compensation levels and performance appraisal processes.

Work autonomy and challenges in job are provided to the role of managers and staff employees. Autonomy is designed referring to the level of the positions. The autonomy is configured based on the level of the position relevant to the freedom to determine their work rules and objectives. Incorporating KPI and Balanced Scorecard within the job description are the reference that can be used by the employees in aiming their objectives.

Employees play a significant role in decision making process. Managers and staff employees are given the same opportunity to provide advice and input on business activities. However, the role of decision maker is at supervisor or manager level. Even though the opportunity is open for an employee to provide input during brainstorming or idea generation process, he/ she must respect to the hierarchy that the decision maker is his/ her superior. Whenever the decision is determined in alignment with company vision, mission and values, all of team or organization members must agree to execute and implement the decision with understanding that the decision is important not only for the organization but also the employees.

Employees are expected to follow and participate in the training and development activities programmed by HR department or their respective department. Many types of training and development could be set up i.e. leadership/ managerial trainings, language trainings, skill development, motivational training and including outbound and team-based training. Employees are required to participate whenever they are scheduled to development activities. The number of training hours for each employee could be utilized as benchmark reference to monitor and ensure the skill \& competency development process is on the way as planned in the beginning of the year.

Performance management is accepted as HR practice within our research participants. In addition to the general implementation of salary structure and scale and minimum wage, performance-based payments will utilize the outcome of performance management process in the company. Performance assessment shall be defined in a standardized and clear procedure for the employees and generally is 
conducted in the same performance process between managers and employees. Striving for an accurate Performance Assessment process is critical in managing employees' commitment. The adherence of the assessment will be maintained if it is regularly conducted, even as intimate as oneon-one session between manager and employees. The process itself is not an isolated process. The assessment can be linked to the company objectives or scorecard, and the result can be linked to employee development activities.

To attract, motivate and retain their employees, companies set a policy line which is at market or higher e.g. utilizing P50 as their salary policy. This policy shall be supported with the implementation of salary structure and scale.

\section{Conclusion}

We explore the practices of human resources in the hospitality industry to understand the practices that apply to managers and staff employees. We find that there are practices that are applied equally between managers and staff employees, and there are also practices that are applied differently specifically to the practice that is linked to the responsibility of a manager to act as a decision maker. Whereas the human resource practices that are applied equally to all employees include corporate values, training, joint activities for employees and families, a clear performance assessment process. To support this approach, the company and the Human Resources department can utilize several tools such as KPI, Balanced Scorecard, Employee Engagement etc. This shows that the hospitality industry can manage an industry level of standard in integrating human resource management to achieve corporate goals.

\section{References}

Ahmed, F, Hassan, A, Ayub, M.U, Klimoski, R 2018, 'High Commitment Work System and Innovative Work Behavior: The Mediating Role of Knowledge Sharing', Pakistan Journal of Commerce and Social Sciences, Vol. 12 (1), pp. 29-51.

Badan Pusat Statistik n.d., Jumlah Akomodasi, Kamar, dan Tempat Tidur yang Tersedia pada Hotel Bintang Menurut Provinsi, 2000-2016. Available from https://www.bps.go.id/dynamictable/2015/12/28/1096/jumlah-akomodasi-kamar-dan-tempattidur-yang-tersedia-pada-hotel-bintang-menurut-provinsi-2000-2016.html (15 October 2018)

Bank Indonesia 2018, Kajian Ekonomi dan Keuangan Regional Laporan Nusantara Edisi Agustus 2018, Volume 13 No 3, ISSN: 2527 - 435X. Available from https://www.bi.go.id/id/publikasi/kajian-ekonomi-regional/laporan-nusantara/Pages/LaporanNusantara-Edisi-Agustus-2018.aspx (15 October 2018)

Davidson, M.C.G, McPhail, R \& Barry, S 2011, 'Hospitality HRM: past, present and the future', International Journal of Contemporary Hospitality Management Vol. 23 No. 4, 2011 pp. 498516, Centre for Tourism, Sport and Service Innovation, Griffith University, Gold Coast, Australia, Emerald Group Publishing Limited 0959-6119

Fenton-O'Creevy, M 1998, 'Employee Involvement and the middle manager: evidence from a survey of organizations', Journal of Organizational Behavior (1986-1998), 1, ABI/INFORM Global pg 67

Huselid, MA 1995. 'The Impact of Human Resource Management Practices on Turnover, Productivity, and Corporate Performance', Academy of Management Journal. Vol 38 No 3. 635-872.

Kwon, K, Bae, J, Lawler J.J 2010, 'High Commitment HR Practices and Top Performers Impacts on Organizational Commitment', Management International Review pp. 50:57-80

Lado, A.A, Wilson, M.C 1994, 'Human Resource Systems and Sustained Competitive Advantage: A Competency-based Perspective', Academy of management Review, Vol. 19, No. 4, p. 699 727. 
Ngo, HY, Lau CM, Foley, S 2008, 'Startegic Human Resource Management, Firm Performance and Employee Relations Climate in China', Human Resource Management, Vol. 47, No 1, Pp. 73 90.

Nickson, D 2007, 'Human Resource Management for the Hospitality and Tourism Industries', Elsevier Ltd, Oxford.

Nuryanti, W 2001, 'Bali and Beyond: Locational Effects on the Economic Impact of Tourism', in Teo, P, Chang T.C, Ho, K.C (eds) 2001, 'Interconnected Words - Tourism in South East Asia', pp. 298 - 311. Elsevier Science Ltd, London.

Oladapo, V, Onyeaso, G 2013, 'An Empirical Investigation of Sub Dimensions Of High Performance Work Systems That Predict Organizational Innovation', International Journal Of Management And Marketing Research, Volume 6, Number 1.

Parnwell, M.J.G 2001, 'Sinews of Interconnectivity: Tourism and Environment in the Greater Mekong Subregion', in Teo, P, Chang T.C, Ho, K.C (eds) 2001, 'Interconnected Words Tourism in South East Asia', pp. 231-247. Elsevier Science Ltd, London.

Pfeffer, J 1998, 'Seven Practices of Successful Organizations', California Management Review, Vol. 40, No. 2, pp. 96-124. 